\title{
Ograniczenia praw politycznych i cywilnych ludności żydowskiej w Księstwie Warszawskim
}

Procesy osadnictwa na ziemiach polskich potomków Abrahama datuje się praktycznie już na sam początek państwowości polskiej. Tradycyjna odrębność ludności żydowskiej skłania wielu autorów do tezy, że naród ten spełniał w Pierwszej Rzeczypospolitej warunki stanu rządzącego się własnymi prawami, poddanego specyficznym ograniczeniom $^{1}$. Sytuacja ta nie odbiegała daleko od praktyki innych państw europejskich, nic więc dziwnego, że rozpad państwowości polskiej nie zmienił wiele w tym względzie, a jeśli już zmienił, to z początku na niekorzyść, gdyż rządy zaborcze wykazywały częstokroć większą niechęć do Żydów niż wcześniejsze rządy polskie ${ }^{2}$. Jednakowoż przemiany, jakim począł podlegać świat w wieku XIX, nie mogły pozostać bez wpływu na ten stan rzeczy.

Do tej pory ludność żydowska nie była w stanie uczestniczyć w życiu politycznym państw, nie dawano jej prawa wyboru i uczestniczenia $\mathrm{w}$ organach przedstawicielskich. Kariera urzędnicza i sądowa Żyda była również praktycznie niemożliwa. Na gruncie prawa cywilnego starozakonni nie mieli równej pozycji na konkurencyjnym rynku, odmawiano im przede wszystkim prawa własno-

1 Por. Żydzi w dawnej Rzeczypospolitej. Materiały z konferencji „Autonomia Żydów w Rzeczypospolitej Szlacheckiej”. UJ, 22-26 IX 1986. Wrocław-Warszawa-Kraków 1991.

2 A. Eisenbach, Emancypacja Żydów na ziemiach polskich 1785-1870 na tle europejskim, Warszawa 1988, s. 125-141. 
ści nieruchomości. Prócz tego ograniczano prawa wynikające z najmu i dzierżawy, zakazywano wykonywania niektórych zawodów, mieszkania w bardziej prestiżowych dzielnicach miast czy też obarczano specjalnymi obowiązkami podatkowymi. Dyskryminacja miała charakter religijny. Żyd po przechrzczeniu zwykle miał szanse na polepszenie swojego statusu społecznego. Żydów postrzegano jako niebezpieczną i wspierającą się konkurencję na rynku, mniejszość głęboko niechętną chrześcijańskiej większości, lud hermetyczny, tajemniczy, obcy w stylu życia, który wymaga bądź to całkowitej przemiany, bądź to całkowitej izolacji.

Utworzone w 1807 roku przez Napoleona Księstwo Warszawskie dawało nadzieję nie tylko na odtworzenie państwowości polskiej, ale i na postępowe reformy społeczne na wzór francuski. Ludność żydowska była tu drugą co do liczebności mniejszością narodową wynosząc według spisu z 1810 roku 300280 osób³ (7\% mieszkańców państwa, $28 \%$ mieszkańców miast) ${ }^{4}$. Żydzi wiązali z przybyciem wojsk napoleońskich na ziemie polskie duże nadzieje, wierząc, że postępowe idee rewolucji doprowadzą do szybkiej i autentycznej poprawy ich sytuacji prawnej.

Symbolem zmian społecznych w Księstwie było wprowadzenie do prawa pojęcia obywatelstwa krajowego. Okrojowana przez Napoleona konstytucja z 22 lipca 1807 roku wprowadzała w art. 4 równość obywateli wobec prawa ${ }^{5}$. Po raz pierwszy przystąpiono na ziemiach polskich do niwelowania głębokich podziałów stanowych. Kwestię obywatelstwa uszczegółowił dekret z 19 grudnia tego samego roku, stanowiąc, że obywatelem będzie każdy urodzony na ziemiach Księstwa oraz każdy od 10 lat mieszkający w kraju i znający język polski. Prócz tego obywatelstwo należało się urodzonym poza granicami państwa w rodzinach obywateli Księstwa oraz żołnierzom armii Księstwa i właścicielom nieruchomości w kraju. Istniała także możliwość nadania obywatelstwa decyzją króla, po

3 B. Wasiutyński, Ludność żydowska $w$ Polsce $w$ wiekach XIX i XX. Studium statystyczne, Warszawa 1930, s. 7.

4 W. Sobociński, Historia ustroju i prawa Księstwa Warszawskiego, Toruń 1964, s. 18.

5 Ustawa Konstytucyjna Księstwa Warszawskiego, Dziennik Praw Księstwa Warszawskiego, nr 1, k. III (dalej: Dz.Pr.Ks.Warsz.). 
przedstawieniu ministra spraw wewnętrznych i wysłuchaniu opinii Rady Stanu ${ }^{6}$.

Za upowszechnieniem praw obywatelskich i politycznych miały iść i cywilne - art. 49 Konstytucji stanowił o wprowadzeniu na terytoriach księstwa Kodeksu Napoleona ${ }^{7}$, który zrywał z feudalną koncepcją własności, odrzucał podziały stanowe i religijne w stosunkach cywilnych. Przy tym politycy polscy $z$ uwagą śledzili stosunek władz francuskich do Żydów w Cesarstwie ${ }^{8}$.

Do władz poczęły tymczasem spływać petycje starozakonnych powołujące się na opublikowane przepisy konstytucyjne, domagające się uznania ich praw obywatelskich ${ }^{9}$. Politycy zaniepokojeni takim obrotem spraw postanowili im skutecznie przeciwdziałać. Ułatwieniem okazały się zresztą właśnie rozwiązania francuskie. W dniu 17 marca 1808 roku wydano we Francji trzy dekrety cesarskie poświęcone Żydom. Pierwsze dwa dotyczyły kultu, trzeci zaś praw cywilnych. Chcąc poprawić sytuację na wsi, unieważniono większość wierzytelności żydowskich wobec właścicieli ziemskich. Zajmowanie się przez Żyda handlem uzależniono od specjalnego patentu; ograniczono prawa do osiedlania się i migracji; nakazano pełnienie osobistej służby wojskowej. Dekrety miały obowiązywać 10 lat - wyrażano nadzieję, że przez ten czas dojdzie we Francji do pełniejszej asymilacji, że znikną „cechy, które odróżniają Żydów od innych obywateli imperium" ${ }^{10}$. Powyższe rozwiązania, choć nienaruszające praw politycznych ludności żydowskiej pod berłem Napo-

\footnotetext{
6 Dekret z 19 XII 1807 r., Dz.Pr.Ks.Warsz., nr 1, s. 3-6.

7 Ustawa Konstytucyjna Księstwa Warszawskiego, k. XXXVI.

8 Kwestia rozstrzygnięcia, czy Żydzi stanowią odrębny naród, była jedną z przyczyn zwołania przez Napoleona zgromadzenia notabli żydowskich 26 lipca 1806 roku. Wyrazili oni lojalność państwu i jego prawu, uznali Francuzów za braci i nie uchylili się przed służbą w obronie kraju. Deklaracje te potwierdził Wielki Sanhedryn - instytucja wzorowana na starożytnym zgromadzeniu wydającym najwyższe przepisy prawne i regulująca kwestie religijne. Jednocześnie zaczęto używać określenia „Izraelita”, chcąc wskazać na stricte religijny charakter odrębności Żydów (A. Eisenbach, Emancypacja Żydów na ziemiach polskich, s. 146-149).

9 Por. Akta Komisji Rządowej Spraw Wewnętrznych, AGAD, sygn. 6627, k. 8-9 (dalej: KRSW).
}

10 A. Eisenbach, op.cit., s. 149. 
leona, stały się pretekstem do wprowadzenia w Księstwie Warszawskim przepisów w te prawa ingerujących. Politycy polscy poczęli zwracać się do króla o podjęcie działań w tej sprawie. I tak minister sprawiedliwości Feliks Łubieński pisał, że „Nowe prawo ustanowione we Francji tymczasowo, [...] dla Naszego Kraju byłoby potrzebne. Nieszczęśliwy sposób wychowania Żydów naszych sprawia, iż za młodu jedynie aplikuje się ich do oszukaństwa, staje się to dla nich nałogiem, potrzebą i źródłem zguby dla poddanych WKM. Byłoby moim zadaniem, żeby to prawo tymczasowe przez 10 lat trwać mające rozciągnąć na Księstwo Warszawskie, z zastrzeżeniem cofnięcia tego, jeżeli Izraelici odmienią przez ten czas zwyczaje swoje" ${ }^{11}$.

W obliczu zbliżających się wyborów do sejmu, 7 września 1808 roku wydano dwa dekrety. Pierwszy mówił o warunkach uzyskania praw politycznych w Księstwie Warszawskim, o podziale kraju na okręgi wyborcze, kompetencjach oraz o trybie obrad zgromadzeń politycznych; drugi wprowadzał tymczasowe zawieszenie praw obywatelskich ludności żydowskiej. Pierwszy z dekretów został opublikowany ${ }^{12}$, ogłoszenie drukiem drugiego zatrzymano ${ }^{13}$.

Używanie praw obywatelskich uzależniono od wpisania na listę obywatelską powiatu lub okręgu gminnego. W opisanych warunkach wpisu oraz w przypadkach jego utraty i zawieszenia nie było mowy o Żydach ${ }^{14}$. Jednak 8 września 1808 roku zobowiązano prefektów do nieumieszczania Żydów w księgach obywatelskich. W przypadku zaś dopominania się Żydów o uznanie ich konstytucyjnych praw cynicznie zalecono prefektom i prezydentom tłumaczenie się „nie-

\footnotetext{
11 KRSW, 6627, k. 63.

12 Dekret z 7 IX 1807 r., Dz.Pr.Ks.Warsz., nr 1, s. 78-115.

13 Dekret z 7 IX 1808 r. dotyczący Żydów: „Uchwalając w załączonym dekrecie naszym pod dniem 7 tego miesiąca przepisy uzupełniające konstytucją Księstwa Warszawskiego w tym, co się tycze zgromadzeń politycznych, znaleźliśmy się powodowani zawiesić jeszcze decyzją naszą względem przypuszczenia ludu starozakonnego do praw obywatelstwa czynnego", Ustawodawstwo Księstwa Warszawskiego, red. W. Bartel, J. Kosim, W. Rostocki, Warszawa 1964, t. I, s. 142 (dalej: Ustawodawstwo Ks. Warsz.).

14 Dekret z 7 IX 1807 r., Dz.Pr.Ks.Warsz., nr 1, s. 79-82.
} 
dostatkiem wyraźnych instrukcji i potrzebą ich szukania"15. Dekret ów, rzecz jasna, również nie doczekał się publikacji.

Zawieszenie praw politycznych Żydów, zrazu nieokreślone w czasie, mocą dekretu z 17 października 1808 roku opatrzono terminem dziesięcioletnim. Wzorem francuskim zaznaczono, że czas ten potrzebny jest na zanik znamion „różniących ich tak bardzo od innych mieszkańców”. Ponadto w art. 2 niniejszego dekretu zagwarantowano szansę uzyskiwania przez poszczególne jednostki indywidualnych zezwoleń dających im możność używania praw politycznych ${ }^{16}$. Warunki uzyskania tej „łaski” miało określić „osobne urządzenie" ${ }^{17}$. Podobnie jak wcześniejszy dekret, ograniczenie to, łamiące w oczywisty sposób postanowienia konstytucji ${ }^{18}$, nie zostało opublikowane; zawiadomiono o nim tylko władze lokalne: 26 października 1808 roku minister spraw wewnętrznych przesłał prefekturom kopie dekretu z 17 października z poleceniem ścisłego stosowania ${ }^{19}$.

Powyższymi postanowieniami uniemożliwiono praktycznie udział Żydów w życiu politycznym Księstwa zarówno na szczeblu centralnym, jak i lokalnym, czy to na forum sejmu, czy też rad miejskich. Na skutek tej linii polityki nie uległy zmianie od dawna stosowane

15 Dekret z 8 IX 1808 r., Ustawodawstwo Ks. Warsz., t. I, s. 143.

16 Dekret z 17 X 1808 r., Ustawodawstwo Ks. Warsz., t. I, s. 148.

17 Takie „urządzenie” nigdy się nie ukazało i faktycznie nie dochodziło do wyjątkowego dopuszczania zasłużonych Żydów do praw obywatelskich i politycznych, nawet w rzadkich przypadkach ich służby w armii, która jak już tu nadmieniono - mocą dekretu z 19 XII 1807 r. miała czynić żołnierza obywatelem. Skądinąd tabela opłat stemplowych uchwalona przez Sejm 24 III 1808 r. przewidywała opłatę za przywilej nadania Żydowi dziedzicznego prawa obywatelstwa. Wynosić ona miała aż 2400 zł (Dz.Pr. Ks.Warsz., t. 3, nr 25, s. 47).

18 Mając tego świadomość, władze zwróciły się o aprobatę Napoleona. Cesarz nie odpowiedział nawet na pismo króla, w którym Fryderyk pisał, iż „wydaje się nie ulegać wątpliwości, że liczna klasa Żydów zamieszkałych w Księstwie Warszawskim jako właściciele nieruchomości, kupcy i fabrykanci nie może rościć sobie pretensji do utrzymania wszystkich uprawnień, które konstytucja przyznaje obywatelom nieszlachcie”, cyt. za: A. Eisenbach, op.cit, s. 150-151.

19 KRSW, 6601, k. 4. 
zakazy pełnienia przez nich urzędów państwowych, zajmowania się niektórymi zawodami (choćby prawniczymi), wchodzenia do cechów rzemieślniczych i zrzeszeń kupieckich. W niektórych sprawach przed sądami zdolność prawna Żydów była jak dawniej ograniczana (m.in. przy sporządzaniu aktów notarialnych) ${ }^{20}$.

Za restrykcyjnymi decyzjami w sferze praw obywatelskich i politycznych poszły ograniczenia w dziedzinie prawa prywatnego. Według wprowadzonego w Księstwie francuskiego Code Civile praw cywilnych używać mogli wszyscy obywatele ${ }^{21}$. Cudzoziemcowi przysługiwały natomiast takie same prawa cywilne, jakie były udzielone obywatelom przez traktaty z narodem, do którego ów cudzoziemiec należał ${ }^{22}$.

Tłumacząc pojęcie „obywatel” („Francuz”), Delsol wskazuje, że wedle dawnego prawa francuskiego obywatelstwo nabywało się przez samo urodzenie na terytorium Francji, nawet $z$ rodziców cudzoziemców, lecz stopniowo okolicznością decydującą o narodowości stało się nie miejsce urodzenia i pochodzenie, ale już tylko pochodzenie - urodzenie $z$ rodziców Francuzó $w^{23}$. Patriarchalny charakter Kodeksu wykazuje treść art. 12 - „Cudzoziemka, która zaślubiła Francuza, przybiera stan swego męża”24. Dzieci z takiego związku spełniały wymogi narodowości francuskiej.

Oddając prawa cywilne w ręce ogółu społeczeństwa, w tym i Żydów, Kodeks kontynuował pracę rozpoczętą prawami rewolucyjnej Francji - dziełami Konstytuanty i Konwentu. Likwidowano wówczas przywileje stanowe, płciowe, odzierano z ograniczeń prawo własności prywatnej, wprowadzano swobodę umów czy też małżeństwa cywilne i rozwody. Podstawowy kierunek rozwoju ku swobodzie jednostek w ich działalności gospodarczej został zachowany, choć w szczegółowych przepisach Kodeksu zawarto wiele $z$ ducha dawnego prawa francuskiego i rzymskiego, co nadało całości wymiar rozsądnego i trwałego konsensusu. W inną stronę poszły jednako-

\footnotetext{
20 A. Eisenbach, op.cit, s. 152-153.

21 Kodeks Napoleona, Warszawa 1810, ks. I, art. 8.

22 Ibidem, art. 11.

23 J.J. Delsol, Zasady kodeksu Napoleona, t. I, Warszawa 1874, s. 34-35.

24 Kodeks Napoleona, ks. I, s. 6.
} 
woż przepisy dotyczące prawa rodzinnego, wykazujące patriarchalizm inicjatora kodyfikacji, „konserwatywnego Korsykanina” ${ }^{25}$.

Jak wcześniej nadmieniono, kwestia praw cywilnych nacji żydowskiej budziła już w samej Francji liczne kontrowersje, co pomimo teoretycznego uznania praw politycznych Żydów, doprowadziło do wprowadzenia w życie praw ograniczających czasowo ich wolność gospodarzenia w Cesarstwie (wspomniany dekret z 17 marca 1808 roku). Tym większą nieufność budziły opisane powyżej rewolucyjne przepisy na ziemiach polskich, gdzie nie doszło do rewolucji burżuazyjnej, a podziały społeczne były o wiele głębsze niż na zachodzie Europy.

Uznanie nienaruszalności własności prywatnej podobało się szlachcie Księstwa Warszawskiego, jednak niepokojem napawał ją fakt, że odtąd trzeba się dzielić prawami z przedstawicielami niższych stanów. W niecały miesiąc od wejścia w życie Kodeksu Rada Stanu wyraziła zdanie, że „ogólne jest dozwolenie kupowania dóbr wszystkim bez różnicy; samo jednak ich nabycie nie nadaje przywileju szlachectwa, ale ten zależy od łaski króla" ${ }^{26}$. Tymczasem już w lipcu 1808 roku minister spraw wewnętrznych Jan Łuszczewski polecił prefektom stosować wobec Żydów przepisy dawnego prawa pruskiego ${ }^{27}$, które jako oparte na stanowym $z$ gruntu Landrechcie Pruskim i Statucie Generalnym dla Żydów z 17 kwietnia 1797 roku uniemożliwiały praktycznie zakup dóbr ziemskich.

Generalne Urządzenie Żydów w prowincjach Prus Południowych i Nowo-Wschodnich z 1797 roku uzależniało od zgody władz administracyjnych (kamer) możność zmiany przez Żyda „miejsca pomieszkania i sposobu życia swego” (rozdz. II, art. 1). Z kolei Żyd parający się kupiectwem lub innym miejskim zawodem mógł posiadać dom w mieście (rozdz. II, art. 2). Prawo do budowy domu, po otrzymaniu stosownego zezwolenia, można było uzyskać w przypadku placu będącego własnością Żyda, ewentualnie nieposiada-

25 K. Sójka-Zielińska, Kodeks Napoleona. Historia i współczesność, Warszawa 2007, s. 93.

26 Protokoły Rady Stanu Księstwa Warszawskiego, red. B. Pawłowski, t. I, cz. 1, Toruń 1960, s. 348 (dalej: Protokoły Rady St. Ks. Warsz.), sesja nr 138 z 24 VI 1808 r.

27 KRSW, 6627, k. 102. 
jącego właściciela lub przez kogoś ustąpionego - gdy nie znajdował się „chrześcijański obywatel” mający to samo pragnienie (rozdz. II, art. 5). Na równi $z$ innymi Żydzi mogli swe posiadłości sprzedawać i pozostawiać sukcesorom i potomkom (rozdz. II, art. 6) ${ }^{28}$.

Generalne Urządzenie Żydów pruskich sankcjonowało przywileje miast, w których zakazywano Żydom mieszkać w pewnych częściach aglomeracji. Gdy jednak znajdowały się w nich puste place, na których chrześcijanie budować się nie chcieli, nakazywało wydawanie chętnym Żydom pozwoleń na budowę i mieszkanie (rozdz. II, art. 7). W artykule następnym wyraźnie zachęcano miasta do znoszenia tychże przywilejów „po należytym roztrząśnieniu okoliczności i przyczyn" ${ }^{29}$. Natomiast w kwestii gruntów wiejskich prawo pruskie dopuszczało nabywanie ich przez Żydów tylko w sytuacji, gdy chodziło o grunty puste - „aby się budowali i gospodarstwo nowe założyli”, zyskując przy tym analogiczne do gruntów chrześcijańskich „dobrodziejstwa i wolności” (rozdz. III, art. 15) ${ }^{30}$.

Celem ostatecznego rozstrzygnięcia tychże kwestii minister Feliks Łubieński zwrócił się do Rady Stanu z pytaniem o sens pozwolenia Żydom nabywania dóbr dziedzicznych. Zauważył przy tym, że „Żydzi w powszechności nie powinni być uznani za obywateli kraju, w którym składają część zupełnie odosobnioną od ogółu społeczeństwa i obcą dla tej ziemi"31. Uzyskał on z miejsca poparcie ministra Łuszczewskiego, który do tychże uwag dodał refleksję o „niskim stopniu cywilizacji tutejszych Żydów w porównaniu do innych krajów"32. Zamieszkiwanie Żydów na wsi uznawano za zjawisko pożyteczne, mające ich odzwyczajać od „szachrajstwa”, jednak - jak wskazywał w swym piśmie do Łuszczewskiego prefekt Departamentu Łomżyńskiego - „pozwolić na nabywanie dziedzicznych gruntów, to nagle

28 Generalne Urządzenie Żydów w prowincjach Prus Południowych i Nowo-Wschodnich, wyd. także w języku polskim, Wrocław 1797, AGAD, Rada Ministrów Księstwa Warszawskiego, sygn. 167, k. 34 (dalej: Generalne Urządzenie Żydów).

29 Ibidem, k. 44.

30 Ibidem, k. 49.

31 Protokoły Rady Stanu Ks. Warsz., t. I, cz. 2, Toruń 1962, s. 232-233, sesja 218 z 15 XI 1808 r.

32 Ibidem, s. 233. 
powstać przeciwko Narodowi”, gdyż żydowscy osadnicy wspólnie z żydowskimi przemysłowcami i handlowcami niechybnie szkodziliby interesom narodu ${ }^{33}$.

W odpowiedzi na te postulaty Rada Stanu wyraziła zdanie o potrzebie „ogólnego urządzenia względem Żydów”, wyznaczając jednocześnie deputację ${ }^{34}$ celem przygotowania jego projektu. Zwrócono się przy tym do króla o upoważnienie ministra sprawiedliwości do odpowiedzi na wątpliwości trybunałów słowami, że „wolność nabywania przez Żydów dóbr dziedzicznych jest zawieszoną do dalszej decyzji” "35. Król przychylił się do tych postulatów i 19 listopada 1808 roku wydano dekret uniemożliwiający Żydom zakup dóbr ziemskich na prawie dziedzicznym. Znów nie poddano go publikacji i dla odparcia zarzutu o łamanie Kodeksu, ujęto w postać zawieszenia uprawnień starozakonnych na lat $10^{36}$.

Szybko okazało się, że wprowadzanie w życie przepisów niezgodnych $z$ wcześniej ustalonymi prawami budzi liczne kontrowersje, spory i niejasności. I tak choćby w kwestii czynności sankcjonujących nabycie nieruchomości. Jednym $z$ wymogów było wówczas przedłożenie organom sądowym listy obywatelskiej kupującego. Kwestię tę poruszył w reakcji na pytanie pisarza aktowego Wollenhaupta notariusz przy Sądzie Kasacyjnym w Rawiczu. Pytanie o sens utrzymywania tego warunku trafiło do ministra Łubieńskiego, a stało się to na dwa dni przed wydaniem wspomnianego dekretu. Prócz tego w liście poruszono kwestię żydowską, a mianowicie, czy wymagane jest zezwolenie władz administracyjnych na zakup przez starozakonnych nieruchomości z rąk chrześcijańskich: „Czy obowiązany jestem stosować się do rzeczonego rozporządzenia prefektury, chociaż mi nie jest publikowane, przez zwierzchność

\footnotetext{
33 KRSW, 6627, k. 81-82.
}

34 W składzie jej znaleźli się minister sprawiedliwości, minister spraw wewnętrznych oraz radcy: Linowski, Węgliński, Woronicz, Rzętkowski, a także referendarz Woyda. Komisja dyskutowała m.in. nad wysiedlaniem Żydów ze wsi i wprowadzenia we wszystkich miastach gett żydowskich, jednak jej pomysły nie wyszły poza fazę projektów (KRSW, 6627, k. 161$-183,207)$.

35 KRSW, 6627, k. 81-82.

36 Dekret z 19 XI 1808, Ustawodawstwo Ks. Warsz., t. I, s. 159. 
przedłożone" 37 - chodziło o sprzeczny z Kodeksem reskrypt prefektury z 26 września tegoż roku, który zakazywał nabywać Żydom nieruchomości od chrześcijan bez jej zgody aż do czasu nowych rozporządzeń $\mathrm{w}$ tej sprawie ${ }^{38}$. W obliczu tego minister Łubieński ${ }^{39}$ zwrócił się o opinię do ministra Łuszczewskiego. Ten przychylił się do zdania o bezużyteczności warunku przedstawiania listy obywatelskiej, jednakowoż w kwestii żydowskiej wskazał na świeżą regulację z 19 listopada jako rozstrzygnięcie wszelkich wątpliwości ${ }^{40}$.

Ograniczenia wspomnianych praw cywilnych Żydów uznawano powszechnie jako niełamiące przepisów kodeksowych. Powoływano się na ich „policyjny” i tymczasowy charakter, a także na możliwość limitacji „prawami albo urządzeniami” używania prawa własności, co przewidywał art. 544 Kodeksu. Niezależnie od kwestii zasadności tych argumentów, unormowania te znowu nie okazały się klarowne we wszystkich przypadkach. Problemem była przede wszystkim interpretacja słowa „dobra” - czy należało odnosić je tylko do nieruchomości wiejskich, czy też do wszystkich nieruchomości. Nie było jasności co do kwestii nabywania domów i pustych placów położonych w granicach miast, który to problem potwierdził m.in. casus Żyda Neumana, pragnącego nabyć dom z gruntem i łąkami w Jaraczewie. Na pytanie ministra policji, czy Żydzi mogą nabywać w miastach domy z gruntami i łąkami, Rada Stanu w grudniu 1808 roku wpierw odpowiedziała, że jest to dozwolone w przypadku gruntów pustych, które miałyby być obrabiane przez samych starozakonnych, $z$ wyłączeniem jednak miast, gdzie funkcjonują zakazy osiedlania się Żydów ${ }^{41}$. Niecały tydzień później Rada, wracając do

37 KRSW, 4114, k. 4.

38 KRSW, 6583, k. 4.

39 W późniejszej opinii skierowanej do Rady Ministrów Łubieński pisał: „Nabywanie własności nieruchomych nie może być podług mego zdania wypływem $z$ praw obywatelskich, lecz raczej wynika $z$ używania praw cywilnych, których wszyscy mieszkańcy kraju równie jak osoby nawet zagraniczne używają”. AGAD, sygn. Rada Ministrów Księstwa Warszawskiego, 167, k. 1, (dalej: Rada Min. Ks. Warsz.).

40 KRSW, 4114, k. 5.

41 Protokoły Rady St. Ks. Warsz., t. I, cz. 2, s. 284, sesja 233 z 10 XII $1808 \mathrm{r}$. 
tejże sprawy, przychyliła się do opinii referendarza Woydy, który udowodnił, że dekret z 19 listopada 1808 roku nie uchyla w kwestiach posiadłości miejskich regulacji pruskich z 17 kwietnia 1797 roku i że nadal należy je stosować ${ }^{42}$.

Jedyną regulacją ustanowioną w Księstwie, która przyzwalała Żydom na zakup posesji miejskich, był dekret z 7 września 1809 roku, wyjaśniający i uzupełniający przepisy w sprawie zamieszkania starozakonnych w Warszawie $z 16$ marca 1809 roku. $Z$ warunków, które akt z 16 marca przewidywał dla maksimum dwóch rodzin żydowskich, chcących nadal mieszkać w strefie zakazanej, wybrano trzy punkty: prawo nabywania pustych placów w strefie niezakazanej dano piszącym i czytającym po polsku, francusku lub niemiecku, posyłającym dzieci do szkół publicznych i nienoszącym się po żydowsku. Warunkiem było wymurowanie domu określonej wielkości. Te same osoby mogły też nabywać domy i budynki drewniane przy ulicach dozwolonych, $z$ tym że objęcie ich w posiadanie mogło nastąpić dopiero po ich rozebraniu i wybudowaniu domu murowanego - w określonym ku temu terminie ${ }^{43}$.

W czerwcu 1810 roku minister spraw wewnętrznych zwrócił się do Rady Ministrów z pismem, w którym zawarł uwagę o potrzebie zwrócenia się do króla o wydanie stosownego dekretu, który miałby zawierać wyraz „dobra” w znaczeniu jurydycznym - jako odnoszący się nie tylko do dóbr ziemskich, ale do wszystkich nieruchomości ${ }^{44}$.

W lipcu 1810 roku minister Łuszczewski zaproponował pierwszy projekt nowego prawa regulującego kwestie własnościowe Żydów. Podkreślił w uzasadnieniu do niego, że wcześniejsze ustalenia (dekret $\mathrm{z} 7$ września 1809 roku) są niewystarczające i należy pozwolić Żydom na kupno w miastach poza domami drewnianymi także murowanych - jednak pod pewnymi ograniczeniami, które brać się miały głównie $z$ przymiotów oznaczonych dekretem z 16 marca 1809 roku. Żydzi nieposiadający tychże znamion nie mogliby nabywać

42 Protokoły Rady St. Ks. Warsz., t. I, cz. 2, s. 293-294, sesja 236 z 16 XII 1808 r.

43 Dekret z 7 IX 1809 r., Ustawodawstwo Ks. Warsz., t. II, s. 89-90.

44 Rada Min. Ks. Warsz., 167, k. 1. 
domów ani placów na ulicach zakazanych, poza domami narożnymi, których nabywanie zakazane miało być im w ciągu roku. Nabywane prawa nie miałyby dawać jednak Żydom praw politycznych w gminach, wyłączona byłaby też możność zaciągania długów hipotecznych $^{45}$.

Po otrzymaniu uwag ministrów sprawiedliwości ${ }^{46}$ i policji ${ }^{47}$ minister Łuszczewski złożył Radzie Ministrów ostateczny projekt, który przyjęto dnia 20 listopada 1810 roku. Wyraźnie przejęto tam określenie „dobra” z dekretu z 19 listopada 1809 roku, na oznaczenie posiadłości ziemskich, nie zaś domów lub pustych placów w miastach. Te ostatnie pozwolono nabywać, jednak pod istotnym ograniczeniem - mogły się one znajdować jedynie w częściach miast specjalnie dla zamieszkiwania starozakonnych wytyczonych. W przypadku Warszawy Żyd chcący nabyć posesję w części niezakazanej winien wykazać, że jest fabrykantem bądź kupcem prowadzącym „znaczący handel” i posiadającym z racji tego „czysty i niewątpliwy majątek". Na nabycie takiegoż domu konieczne było zezwolenie, które wydawać miał minister spraw wewnętrznych po wcześniejszym przedłożeniu sprawy przez władze administracyjne miasta.

Wyjątkowo dozwolony zakup posesji w częściach miast zakazanych miał być jak dotąd regulowany przepisami ze wspomnianego dekretu z 16 marca 1809 roku, zakazującego ludności żydowskiej mieszkania przy pewnych ulicach Warszawy (o nim szerzej w dalszej części pracy). Rozpoznawanie przymiotów „uprzywilejowanych” Żydów miało należeć do władz miejscowych, samego zaś zezwolenia miał udzielać minister spraw wewnętrznych. Zamieszkiwać mógł tam Żyd ze swoją rodziną tylko wówczas, gdy na danej ulicy nie była usytuowana już inna rodzina starozakonna, chyba że używała tegoż prawa na zasadzie art. 4 wspomnianego dekretu ${ }^{48}$.

Król odpowiedział dopiero 16 października 1811 roku. Zwrócił uwagę, że projekt „stanowi prawo pomniejszające ogólne prawidła”

\footnotetext{
45 Ibidem, 167, k. 5.

46 Ibidem, k. 27.

47 Ibidem, k. 63-64.

48 Ibidem, k. 74-76.
} 
i w takiej formie jest niemożliwy do przyjęcia, jako sprzeczny „Z duchem i materią Kodeksu”, a dokładnie z artykułami 1123, 1594 i $1598^{49}$. Król zasugerował, by kwestię tę w Księstwie objąć regulacją o charakterze tymczasowym i policyjnym, na wzór wspomnianego już tu dekretu Napoleona ograniczającego niektóre prawa cywilne starozakonnych we Francji z 17 marca 1808 roku. Fryderyk August postulował nie wyłączać $z$ regulacji żadnego przedmiotu własności, a określić nabywanie i używanie jej pod pewnymi warunkami; wyznaczyć czas trwania i powody. „Regulacja policyjna miałaby tutaj za cel swój przepisanie każdemu w szczególności mieszkańcowi sposobu takiego używania własności, jaki dla dobra ogółu jest najdogodniejszym", pisał król, powołując się kolejny raz na art. 544 Kodeksu, limitujący swobodę używania własności obowiązującymi prawami i urządzeniami ${ }^{50}$.

W ostateczności w Księstwie Warszawskim nie doszło do bardziej szczegółowych regulacji dotyczących praw Żydów do nabywania nieruchomości. Podczas gdy skrupulatnie dbano o przestrzeganie zakazu nabywania przez Żydów majątków wiejskich, to w wypadku nieruchomości miejskich panował formalny i praktyczny nieład. Jak relacjonował ministrowi Łuszczewskiemu prefekt warszawski, po usunięciu władz pruskich w wielu miastach Księstwa początkowo nie stwarzano Żydom żadnych przeszkód formalnych przy nabywaniu placów i domów $\mathrm{z}$ rąk chrześcijan, w innych natomiast nadal stosowano regulacje pruskie ${ }^{51}$. $Z$ uwagi na to, że pozwalały one na kupno nieruchomości miejskiej przez Żyda w wypadku braku ofert chrześcijan, urządzano licytacje publiczne. Gdy nie stawiał się na nie żaden chrześcijanin, spisywano protokół licytacji z zaświadczeniami uczynionych obwieszczeń, następnie przesyłano go władzom administracyjnym (w czasach pruskich - kamerze, w czasach Księstwa - prefektowi), które wydawały stosowny kon-

\footnotetext{
49 Ibidem, k. 87.

50 Ibidem, k. 87-89.

51 W czasach pruskich również pojawiały się trudności $z$ egzekucją przepisów nakazujących uzyskiwanie przez Żydów zezwoleń na nabywanie nieruchomości miejskich, czego dowodem było publicandum z $28 \mathrm{~V} 1806$ r., wprowadzające karę 50 talarów za złamanie w tej kwestii Generalnego Urządzenia Żydów z 1797 r. (KRSW, 6583, k. 21).
} 
sens $^{52}$. Z kolei 24 marca 1809 roku uchwała sejmowa o opłatach stemplowych ustaliła kwotę 90 zł za udzielenie zezwolenia na nabycie placu w mieście $z$ rąk chrześcijańskich ${ }^{53}$, przy czym nie wyjaśniono, w jakim zakresie stosować należy tu prawa pruskie. Alarmowany przez prefektów w tej sprawie minister Łuszczewski sporządził projekt nowego prawa nabywania przez Żydów posiadłości miejskich i przedłożył go Radzie Ministrów, a przy tym wydał 21 listopada 1810 roku reskrypt nakazujący do czasu ustanowienia tejże regulacji w każdym przypadku przesyłać mu żydowskie prośby o zezwolenia na nabycie domów i placów miejskich wraz z opiniami władz lokalnych ${ }^{54}$. W ostateczności to minister spraw wewnętrznych decydować miał o każdorazowym udzieleniu zezwolenia, co doprowadziło do zalewu ministerstwa prośbami i petycjami starozakonnych, na co sam Łuszczewski wielokrotnie się uskarżał i co było dlań argumentem za przyjęciem jego projektu rodzimego prawa. Minister spraw wewnętrznych podkreślał, że do tego czasu regulację pruską należy stosować w zakresie, w jakim „się nie sprzeciwia duchowi konstytucji, kodeksowi cywilnemu, uchwałom sejmowym i dekretom Najjaśniejszego Pana"55.

Ograniczeniom w zakresie nabywania nieruchomości w miastach towarzyszyły przepisy wytyczające strefy, w których Żydzi mieszkać nie mogli. Powoływano się tu na dawne przywileje miejskie, które od wieków pozwalały magistratom wytyczać getta. W przypadku Warszawy stosowano natomiast regulację pruską z 26 czerwca 1806 roku o usunięciu starozakonnych $z$ głównych ulic miasta. W grudniu 1808 roku w reakcji na petycje Żydów proszących o cofnięcie pruskiego nakazu ${ }^{56}$ minister spraw wewnętrznych przekonał radców, że ten pozostaje użyteczny, bo jako regulacja o charakterze policyjnym nie narusza praw obywatelskich jego adresatów, tym bardziej że - jak stwierdził - „nawet nie są jeszcze Żydom bez wyłą-

52 KRSW, 6583, k. 19-20.

53 Ustawa Sejmu o opłatach stemplowych w sprawach administracyjnych z 24 III 1809 r., Dz.Pr.Ks.Warsz., t. 3, nr 25, s. 47.

54 KRSW, 6583, k. 22.

55 Ibidem.

56 Wyznaczony przez władze pruskie termin wyprowadzenia się Żydów z zakazanych stref Warszawy upływał w Wielkanoc 1809 r. 
czenia przyznane”. Minister zasugerował jedynie wprowadzenie do pruskiej regulacji pewnych modyfikacji, w tym zmiany terminu opuszczenia przez Żydów swych mieszkań „z powodu, iż ci po zmianie okoliczności krajowych będąc w nadziei, że urządzenie przeszłego rządu do skutku nie przejdzie, nie przygotowali się do wyruszenia z teraźniejszych mieszkań”. Dyskusja w kwestii, czy na korzyść petentom może służyć ich ewentualna zmiana ubiorów na „chrześcijańskie”, została zakończona przyjęciem tezy radcy Linowskiego, że „samo przebranie Żydów nie odmieni ich obyczajów i złych nałogów". $Z$ kolei zwrócono uwagę, by w przygotowywanej regulacji warszawskiej zawrzeć odstępstwa na korzyść przedstawicieli „postępowych" profesji, takich jak lekarze, malarze czy stolarze ${ }^{57}$.

Ostatecznie postanowiono sporządzić nową regulację warszawską, kontynuującą zamierzenia pruskie. Efekty prac nad nią deputacja przedstawiła Radzie Stanu na sesji z dnia 24 lutego 1809 roku, otrzymując wcześniej poparcie ministra spraw wewnętrznych. Projekt zawierał wyliczenie ulic wzbronionych, określał możliwość zamieszkania na każdej z nich dwóm starozakonnym rodzinom „postępowym”, a także zasady lokowania Żydów na ulicach niewyłączonych tą regulacją ${ }^{58}$. Na sesjach w lutym ${ }^{59}$ i w marcu ${ }^{60}$ ustalono jeszcze, że kolejnym wyjątkiem od zakazu zamieszkiwania przy znaczniejszych ulicach będzie sytuacja, gdy na pustym placu przy wymienionych ulicach Żyd wymurował dom z poszanowaniem wszystkich przepisów policyjnych.

Nowe prawo przybrało formę dekretu królewskiego $\mathrm{z}$ dnia 16 marca 1809 roku $^{61}$. Wymienił on listę dzielnic i ulic zakazanych (art. 2), dozwalając jednocześnie mieszkać na każdej z ulic dwóm rodzinom żydowskim, pod pewnymi warunkami (art. 3). Były to: posiadanie czystego majątku w postaci 60 tys. zł, wykonywanie zawodu bankiera lub prowadzenie handlu „przyzwoitego i otwar-

57 Protokoły Rady St. Ks. Warsz., t. 1, cz. 2, s. 317, sesja 244 z 30 XII $1808 \mathrm{r}$.

58 Ibidem, t. 2, cz. 1, Toruń 1965, s. 112-113, sesja 277 z 24 II 1809 r.

59 Ibidem, s. 124, sesja 280 z 28 II 1809 r.

60 Ibidem, s. 130, sesja 282 z 2 III 1809 r.

61 Dekret z 16 III 1809 r., Ustawodawstwo Ks. Warsz., t. II, s. 26-30. 
tego", wykazywanie się umiejętnością czytania i pisania po polsku lub francusku, lub przynajmniej po niemiecku, posyłanie dzieci do szkół publicznych oraz nieużywanie „znaków powierzchownych, które dotąd lud starozakonny od innych mieszkańców odróżniają”.

Prócz tego na każdej $z$ tych ulic mógł mieszkać ze swą rodziną jeszcze Żyd dopełniający trzy ostatnie warunki $z$ art. 3, a przy tym „nauce poświęcony lub sztuce wyzwolonej biegły” - po złożeniu stosownego świadectwa od Dyrekcji Edukacyjnej - oraz ten, który posiadałby użyteczną krajowi fabrykę wzniesioną rękoma ludzi swego wyznania (art. 4).

Dekret zajął się też problemem zbytniego zagęszczenia rodzin starozakonnych na ulicach niezakazanych, wytyczając ich liczbę $\mathrm{w}$ proporcji do izb przeznaczonych do wynajęcia w jednym domu (art. 12). W przypadku zaś domów pustych, opuszczonych przez właścicieli, dozwolono urzędowi policji na wynajmowanie ich Żydom, pod warunkiem ich wyremontowania i dalszego właściwego utrzymywania (art. 13). Artykuł 14 określił warunki formalne umów najmu, art. 15 - wygaśnięcie umów podpisanych na wynajem mieszkań w obszarach zakazanych (rodziny winny wyprowadzić się do dnia 4 października 1809 roku), art. 9 wyznaczył karę dla właściciela łamiącego przepisy - równowartość sumy rocznego czynszu żydowskiego lokatora ${ }^{62}$.

Celem wyjaśnienia i uzupełnienia przepisów z 16 marca 1809 roku we wrześniu tego samego roku wydano kolejny dekret. Zaznaczono tam, że na obszarach zakazanych nie mogą się też mieścić sklepy żydowskie (art. 1); domy narożne przy ulicy zakazanej i dozwolonej zostały uznane za przynależne sferom zakazanym, a zawarte wcześniej kontrakty najmu miały obowiązywać jeszcze przez rok (art. 3); natomiast wynajmowanie Żydom domów opustoszałych poddano przepisom ograniczającym zagęszczenie lokatorów starozakonnych (art. 5) ${ }^{63}$.

Powyższe regulacje wywołały niezadowolenie wielu właścicieli posesji, w których mieszkania wynajmowali Żydzi. Zaczęto kierować

\footnotetext{
62 Ibidem.

63 Dekret z 5 IX 1809 r., Ustawodawstwo Ks. Warsz., t. II, s. 88-90.
} 
do rządu petycje w sprawie utrzymania starozakonnych lokatorów ${ }^{64}$. W obliczu tego minister spraw wewnętrznych począł przekonywać Radę Stanu o potrzebie złagodzenia przepisów, wskazując na to, że przy zawartych wcześniej najmach jeden rok prolongaty nie wystarczy często na zwrot kosztów poniesionych przez właścicieli na reparację domów, ani tym bardziej nie da kapitałów potrzebnych do przystosowania ich do zamieszkania przez chrześcijan (przez co należy zapewne rozumieć konieczność podwyższenia standardu). Sugerował zezwolenie na zamieszkiwanie Żydom w domach narożnych, gdzie część przylegająca do ulicy dozwolonej nie ma żadnej komunikacji z częścią zakazaną: „byleby sklepy ich i wchód do mieszkań na ulicę zakazaną nie wychodziły" ${ }^{65}$. Król przychylił się do tych argumentów i 1 grudnia 1810 roku wydano dekret dający Żydom prawo mieszkania w domach narożnych między ulicą zakazaną i dozwoloną - w części budynków usytuowanej przy ulicy niezakazanej. Jednocześnie uznano, że sklep znajdujący się w rogu dzielącym ulicę zakazaną od dozwolonej będzie uważany za usytuowany na części zakazanej66.

Wzorem stolicy ${ }^{67}$ władze przychylnie reagowały na petycje magistratów innych miast dotyczące rugowania starozakonnych $z$ bar-

64 Między innymi petycja z 22 V 1810 r. właścicieli: Noaka, Brzozowskiego i Weisa, wynajmujących mieszkania w domach narożnych, przylegających do ulic zakazanych i dozwolonych (Rada Min. Ks. Warsz., 166, k. 3-6).

65 Rada Min. Ks. Warsz., 166, k. 10-11.

66 Ibidem, k. 22.

67 Skądinąd dekret z 16 III 1809 r. nie spełnił pokładanych w nim nadziei, czego dowodzi raport ministra policji skierowany do Rady Ministrów 6 X 1812 r. Ukazuje w nim rosnący nieporządek w stolicy, wynikający z przenoszenia Żydów z miejsca na miejsce, rozrzucenia po całym mieście, co utrudniać miało wykonywanie wobec nich zarządzeń policyjnych. Zarzucał starozakonnym „trzymanie Warszawy w oblężeniu” przez skuteczne opanowanie szlaków handlowych, skupowanie na pniu towarów od przybywających na targi chłopów - co miało powodować drożyznę, a także rozpijanie tychże. Minister proponował utworzenie w stolicy faktycznego getta - terenu od miasta odosobnionego, gdzie tylko mogliby Żydzi mieszkać i prowadzić działalność gospodarczą (Rada Min. Ks. Warsz., 165, k. 14). 
dziej prestiżowych ulic. Podkreślano bowiem oficjalnie, że na skutek postępowych reform w Księstwie dawne przywileje tworzące getta nie mogą już mieć zastosowania, natomiast powyższe regulacje mają charakter stricte policyjny i po spełnieniu swego zadania (ujednolicenia społeczeństwa) zostaną zmienione ${ }^{68}$. I tak podobne regulacje ustanowiono we Wschowie (5 lipca 1810 roku) ${ }^{69}$, Płocku

68 Błędne przekonanie o skuteczności dawnych przywilejów antyżydowskich skłoniły magistrat Lublina do skierowania w maju 1811 r. sprzeciwu wobec decyzji prefekta departamentu lubelskiego, które było wykonaniem wcześniejszego reskryptu ministra policji. Jego mocą Żyd Wolf Drezner uzyskał prawo mieszkania w Lublinie, w strefie zakazanej mocą przywileju królewskiego z 17 IV 1780 r. Drezner miał prowadzić tam fabrykę waty, ale wystąpił przy tym o zezwolenie na prowadzenie traktierni i szynku, co wzburzyło władze miasta, które oskarżyły go o nieczyste intencje pod „subtelną maską”. Minister spraw wewnętrznych, przedstawiając 21 VI $1811 \mathrm{r}$. opinię Radzie Ministrów, pisał, że w odróżnieniu od dawnych przywilejów z czasów Rzeczypospolitej, unormowania rządu pruskiego i rządu Księstwa - „ze względu na różnice obyczajów i ucywilizowanie różnych klas mieszkańców”, ich policyjny charakter i cel nadrzędny - ujednolicenie społeczeństwa - nie są sprzeczne z Konstytucją. Zauważył, że „znoszenie wyraźne” dawnych przywilejów miejskich i „dozwalanie Żydom mieszkać, gdzie chcą", byłoby niekorzystne, tym bardziej w obliczu owych postanowień wytyczających strefy zakazane w niektórych miastach. Pomimo tego, że dawne przywileje straciły swą moc prawną, rząd winien brać je pod uwagę - „wzgląd na nie mieć będzie, tyle ile się zgadzać z jego zasadami i dobrym porządkiem rzeczy będą”. Przy tym zaznaczył, że nie może obiecać, iż nie będzie w Lublinie dalszych zezwoleń na wzór Dreznera. W jego przypadku zalecił odrzucenie żądania magistratu przy jednoczesnym zakazaniu prowadzenia szynku (Rada Min. Ks. Warsz., 166, k. 76-79). Opinię tę poparł również minister sprawiedliwości (ibidem, k. 85-86). W podobnej sprawie zwrócił się do ministra spraw wewnętrznych 3 VI 1812 r. prefekt departamentu radomskiego, w związku z powoływaniem się prezydenta Sandomierza na przywilej ograniczający prawo zamieszkiwania Żydów oraz prawo handlu w tym mieście z 1559 r. Argumentem za obowiązywaniem tych obostrzeń było powołanie przez króla Stanisława Augusta Poniatowskiego komisji, która uznała wówczas aktualność tych obostrzeń. Minister zdecydowanie poparł (17 VII 1812 r.) zdanie prefekta, który twierdził, że w obliczu Konstytucji, tego rodzaju przywileje są nieważne (KRSW, 6628, k. 38-39).

69 Rada Min. Ks. Warsz., 165, k. 33. 
(8 listopada 1811 roku) ${ }^{70}$, Makowie (29 stycznia 1813 roku) ${ }^{71}$ i Psasznyszu (29 stycznia 1813 roku) ${ }^{72}$. Wzorowany na warszawskim był również dekret krakowski (19 marca 1812 roku) ${ }^{73}$, z tym że rozszerzał on obszar dozwolony Żydom, dając im prawo mieszkania nie tylko na przynależnym im od czasów Kazimierza Jagiellończyka Kazimierzu żydowskim, ale również na terytorium Kazimierza katolickiego. Jednocześnie utwierdziła się praktyka udzielania zasłużonym Żydom specjalnych zezwoleń na zamieszkiwanie w strefach zakazanych.

W uzasadnieniach polityki wobec Żydów często przewijał się aspekt szczytnego celu represyjnych unormowań, jakim miało być „ucywilizowanie” Żydów, zniechęcanie do prowadzonego stylu życia, zachęcanie do zajmowania się „uczciwą działalnością”.

W dniu 20 marca 1809 roku wydano dekret zachęcający do osiedlania się zdolnych rolników, przemysłowców i rzemieślników $z$ dużymi kapitałami, dając im jednocześnie 6 lat wolności podatkowej oraz zwolnienie od popisu wojskowego (obejmujące również ich dzieci) ${ }^{74}$. Pojawiła się szybko wątpliwość, czy powyższa regulacja stosować się też ma do Żydów cudzoziemców. Reagując na zapytanie prefekta łomżyńskiego, minister spraw wewnętrznych Łuszczewski przedstawił Radzie Ministrów swoje zdanie w tej kwestii. Minister uznał, że starozakonnych należy objąć unormowaniami szczególnymi, dając przywileje jedynie najzdolniejszym i najbogatszym $z$ nich ${ }^{75}$.

70 Ibidem, k. 72-78.

71 Ibidem, k. 95-99.

72 Ibidem, k. 100-105.

73 AGAD, sygn. Rada Stanu Księstwa Warszawskiego i Rada Ministrów Księstwa Warszawskiego, 217, k. 111-114 (dalej: Rada St. Ks. Warsz. i Rada Min. Ks. Warsz).

74 Dz.Pr.Ks.Warsz., t. 3, nr 36, s. 455-458.

75 Dla celów nowej regulacji minister Łuszczewski podzielił Żydów osadników na trzy kategorie. W pierwszej znaleźli się ludzie bez majątku. Bronić przed ich napływem miał Instruktaż Celny z 15 IV 1807 r., wyznaczający zaporową kwotę 300 zł w gotówce lub towarach przy przekraczaniu granicy. Grupę drugą stanowili posiadający ów majątek, jednakże ci nie powinni wg ministra zyskiwać rzeczonych przywilejów z racji prawdopodobnie nikłego pożytku dla kraju. Kategoria trzecia to Żydzi wnoszący do 
Stosowny dekret wydano 30 października 1812 roku. Wyznaczono w nim sumę 60 tys. zł kapitału bez długu jako podstawę do uzyskania przez rzemieślnika, rolnika lub przemysłowca dobrodziejstw dekretu z 20 marca 1809 roku. Prócz tego żydowski przemysłowiec musiał zobowiązać się, że nie założy na terytorium Księstwa fabryki trunków. Wzorem wcześniejszych regulacji dano też zachętę do osiedlania się żydowskim lekarzom, profesorom, czytającym po polsku, francusku lub niemiecku i kształcącym dzieci w szkołach publicznych. Oprócz nich wpuszczani w granice kraju mogli być tylko starozakonni, którzy dysponowali minimum 300 zł majątku i którzy udowodnili przed komisją biegłych przysięgłych, że posiadają umiejętności rzemieślnicze w którymś z wymienionych zawodów ${ }^{76}$. Zobowiązać się przy tym musieli pod karą wyprowadzenia $z$ powrotem za granicę, że przez minimum 5 lat będą tę profesję wykonywać ${ }^{77}$. W sprzeczności $z$ tymi decyzjami stał jednak kolejny zakaz. Uniemożliwiając biednym Żydom przenoszenie się w granice Księstwa, a zachęcając do tego Żydów zasobnych i zdolnych, uniemożliwiono jednak dzierżawienie przez nich dóbr narodowych. W art. 2 mówił o tym dekret z 3 kwietnia 1812 roku o warunkach dzierżawy dóbr narodowych ${ }^{78}$.

Jednym z głównych przejawów „przewrotnego” i „szkodliwego” postępowania Żydów była dla rządzących Księstwem tradycja prowadzenia karczem i szynków. Zarzucano Żydom rozpijanie Polaków, zwłaszcza na wsi. W związku z tym przystąpiono do prac nad regulacją odbierającą starozakonnym prawo do zajmowania się tą działalnością gospodarczą. Minister policji Ignacy Sobolewski przygotował we wrześniu 1812 roku szczegółowy raport w tej sprawie. Dowodził w nim, że nadmierne rozprzestrzenianie się szynków

kraju „taki majątek lub taki gatunek przemysłu lub takie rzemiosło, któreby ich godnymi uczyniły dobrodziejstw Dekretu Królewskiego dnia 20 III 1809 r. zapadłego" (Rada St. Ks. Warsz. i Rada Min. Ks. Warsz., 217, k. 117-123).

76 I tak wpuszczano do Księstwa garbarzy, rymarzy, ślusarzy, sukienników, farbiarzy, postrzygaczy, płócienników, górników, hutników, kowali, nożowników, puszkarzy, stolarzy, kołodziejów i stelmachów.

77 Dekret z 30 X 1812 r., Dz.Pr.Ks.Warsz., t. 4, nr 47, 398-402.

78 Dekret z 3 IV 1812 r., Dz.Pr.Ks.Warsz., t. 4, nr 43, s. 278. 
żydowskich powoduje wzrost przestępczości, natomiast zakaz w tej sprawie skłoni przy okazji wielu starozakonnych do bardziej pożytecznych dla kraju działalności, takich jak rolnictwo ${ }^{79}$. Projekt stosownego dekretu został złożony królowi 8 września 1812 roku ${ }^{80}$. W odpowiedzi król nakazał wniesienie projektu pod obrady Rady Stanu, lecz co ciekawe, po zmianie brzmienia wstępu, który uznał za zbyt drastyczny, ,jawnie wytykający zdrożności ludu starozakonnego"81. Nowa wersja wstępu ${ }^{82}$ została zaakceptowana przez króla i dekret wydano 30 października 1812 roku.

Dekret wyznaczył datę 1 lipca 1814 roku jako moment, od którego zakazywano Żydom „handlować, fabrykować, ani szynkować żadnego gatunku trunków, czy to pod własnym, czy pod cudzym imieniem, czy na własny, czy na cudzy rachunek"83. Zabroniono również mieszkać Żydom w karczmach, szynkach i browarach. Za

79 Rada Min. Ks. Warsz., 168, k. 17-31.

80 Ibidem, k. 32-33.

81 We wstępie do projektu pisano: „Zważywszy, iż prowadzenie przez Żydów handlu, fabrykacji i szynkowania trunków staje się główną przyczyną utwierdzania ludu pospolitego w zgubnym pijaństwa nawyku i przy tym okazują do rozmaitych przestępstw i wykroczeń; Chcąc zachować lud nasz od tych niebezpieczeństw i zarazem przywieść familie żydowskie, dotąd tymi szkodliwymi profesjami bawiące się, do pożyteczniejszych dla Kraju zatrudnień”, ibidem, k. 32.

82 Poprawiony wstęp: „Zważywszy, iż w teraźniejszym Żydów położeniu, prowadzenie przez nich handlu, fabrykacji i szynkowania trunków, staje się szkodliwym dla mieszkańców Księstwa Naszego Warszawskiego, a szczególnie włościan, chcąc oraz przywieść familie żydowskie dotąd tymi profesjami bawiące się, do pożyteczniejszych dla ogółu Kraju zatrudnień”, ibidem, k. 35.

83 Krótko po ustanowieniu zakazu minister Łuszczewski zwrócił się do Rady Ministrów z ponownym wnioskiem w sprawie ułatwienia Żydom nabywania posesji w miastach. Poskarżył się na zalew próśb o zezwolenia na zakup domów przez Żydów. Zwrócił uwagę, że wzbronienie Żydom szynkowania i handlu trunkami odbiera im „najobszerniejszy dotychczas między nimi sposób użycia kapitałów", przez co należy zadbać, by nie uciekały za granicę. Poza tym nowa sytuacja prawna kieruje Żydów ku działalnościom gospodarczym, wymagającym większych nakładów i bardziej stabilnego osiedlania się w konkretnych miejscach kraju. Dopuszczenie w końcu Żydów do swobodnego udziału w obrocie nieruchomościami miejskimi 
złamanie tych regulacji przewidziano surowe kary pieniężne zarówno dla samych Żydów, jak i ich współpracowników, a także urzędników do tego dopuszczających. Zakazano nawet utrzymywania w gorzelniach Żydów pracowników (palaczy i gorzelników), jednak dopiero od dnia 1 lipca 1815 roku $^{84}$. Ostatecznie wprowadzenie tych zakazów zostało wstrzymane przez Radę Najwyższą Tymczasową po rychłym upadku Księstwa ${ }^{85}$.

Ludność żydowska Księstwa obarczona była również szczególnymi obowiązkami podatkowymi. W kwietniu 1807 roku decyzją Komisji Rządzącej utrzymano pruską instytucję geleitzoll, czyli tzw. biletowe. Była to opłata (zależna od statusu społecznego, rodzaju działalności gospodarczej, płci i długości pobytu), jaką wnieść musiał każdy cudzoziemski Żyd przekraczający granicę państwa na pobyt czasowy (maksymalnie 6 miesięcy), zwolnieni zaś od niej byli tylko Żydzi świadczący usługi medyczne (lekarze i akuszerki) ${ }^{86}$. Podatek ten zniesiono 16 stycznia 1810 roku wobec Żydów uprawiających handel tranzytowy ${ }^{87}$. Natomiast po całkowitym zniesieniu ceł tranzytowych w Księstwie (29 listopada 1811 roku) ${ }^{88}$ rozważano poważnie przywrócenie biletowego od Żydów handlujących tranzytem, tak jak nadal płacili go starozakonni trudniący się typowym handlem zagranicznym (zwanym wówczas inwektoryjnym) ${ }^{89}$. W obliczu prawa zakazującego Żydom z Księstwa handlować detalicznie (en detail) na jarmarkach miast pruskich wprowadzono analogiczne regulacje wobec Żydów pruskich, dozwalając im jedynie na handel ryczałtowy (en gros) ${ }^{90}$.

spowodować by miało według ministra spraw wewnętrznych wzrost cen i konkurencji na tym rynku, o tyle istotniejszy w realiach zniszczeń spowodowanych przez aktualne działania wojenne (KRSW, 6584, k. 60-61).

84 Dekret z 30 X 1812 r., Dz.Pr.Ks.Warsz., t. 4, nr 47, s. 393-396.

85 Dokonano tego w czerwcu 1814 r. na prośbę Żydów i za wniesioną opłatą (wg W. Sobocińskiego, op.cit., s. 90).

86 Rada Min. Ks. Warsz., 168, k. 7-10.

87 Dekret z 16 I 1810 r., Ustawodawstwo Ks. Warsz., t. II, s. 108.

88 Dekret z 29 I 1811 r., Dz.Pr.Ks.Warsz., t. 4, nr 37, s. 9-10.

89 Rada Min. Ks. Warsz., 168, k. 11-15.

90 Dekret z 11 II 1811 r., Ustawodawstwo Ks. Warsz., t. III, s. 31. 
Od uchwały sejmowej z 24 marca 1809 roku funkcjonował podatek od rytualnego uboju mięsa, tzw. koszerny, którego pobór $\mathrm{w}$ postaci wypuszczania go w dzierżawę poprzez licytacje stał się treścią dekretu $z$ dnia następnego ${ }^{91}$; mocą dekretu z 22 maja 1810 roku zastąpiono nim analogiczne opłaty austriackie w Galicji, jednocześnie utrzymując na tych terenach „podatek familijny żydowski”, zaprowadzony przez rząd austriacki w sierpniu 1806 roku, z tym że zyski $z$ niego przeznaczono na pokrycie długów żydowskich gmin - kahałów (po ich opłaceniu miał być uchylony) ${ }^{92}$.

W dniu 29 stycznia 1812 roku wprowadzono rekrutowe - ryczałtową opłatę 700 tys. zł rocznie od wszystkich gmin żydowskich w związku $\mathrm{z}$ postulowanym przez starozakonnych uwolnieniem ich od służby wojskowej93; pobierano też opłaty od zgody na zawarcie ślubu żydowskiego ${ }^{94}$ - tę pruską instytucję, zapisaną w Generalnym Urządzeniu Żydów w prowincjach Prus Południowych i Nowo-Wschodnich (rozdz. V, art. 9), utrzymała Komisja Rządząca 14 marca 1807 roku $^{95}$, a ostatecznie określono ją w uchwale sejmowej o opłatach stemplowych z 24 marca 1809 roku (360 zł) ${ }^{96}$, tak jak i kwotę pobieraną za udzielenie zezwolenia na nabycie $z$ rąk chrześcijańskich placu w mieście $(90 \mathrm{zf})^{97}$. Z drugiej strony opłata za zezwolenie prowadzenia handlu była równa dla Polaka i dla Żyda ${ }^{98}$. Za książki i kalendarze w języku hebrajskim, zarówno rodzime, jak i importowane, pobierano mocą instruktarza generalnego Komisji

91 Dekret z 25 III 1809 r., Dz.Pr.Ks.Warsz., t. 2, nr 13, s. 34-36.

92 Dekret z 22 V 1810 r., Dz.Pr.Ks.Warsz., t. 2, nr 18, s. 189-192.

93 Dekret z 29 I 1812 r., Dz.Pr.Ks.Warsz., t. 4, nr 40, s. 159-162.

94 Prawo pruskie przewidywało również specjalną opłatę za ślub z Żydówką z zagranicy, „aby nie odejmować sposobności Żydówkom [krajowym] do zamążpójścia” - wynosiła ona 500 talarów, Generalne Urządzenie Żydów, rozdz. I, art. 16.

95 Uchwała Komisji Rządzącej utrzymująca podatek żydowski od ślubów małżeńskich, 14 III 1807, Materiały do dziejów Komisji Rządzącej, t. I, Dziennik Czynności Komisji Rządzącej, wyd. M. Rostworowski, Kraków 1918, s. 573.

96 Uchwała Sejmu o opłatach stemplowych w sprawach administracyjnych z 24 III 1809 r., Dz.Pr.Ks.Warsz., t. 3, nr 25, s. 47.

97 Ibidem.

98 Ibidem, s. 46. 
Rządzącej z 15 kwietnia 1807 roku wysoką opłatę stemplową, którą podwyższono jeszcze w stosunku do dzieł importowanych dekretem z 6 grudnia 1811 roku $^{99}$.

W praktyce zaprowadzenie na terenie Księstwa nowego porządku prawnego nie spowodowało przemiany, jakiej można było się spodziewać po ideowych hasłach nowej władzy czy nawet jej nowych prawach, teoretycznie równych dla wszystkich. W rzeczywistości poddawano je reglamentacjom przy pomocy przepisów szczegółowych, których zwykle nie publikowano, a częstokroć nadal stosowano dawne lokalne prawa antyżydowskie (zwłaszcza przywileje miejskie) oraz regulacje zaborcze - zwłaszcza Generalne Urządzenie Żydów w prowincjach Prus Południowych i Nowo-Wschodnich ${ }^{100}$.

$Z$ dzisiejszej perspektywy polityka ta jawi się jako sprzeczna z duchem czasów, literą prawa i humanitaryzmem - Żydzi okazują się bowiem chyba najbardziej represjonowaną prawnie grupą społeczną Księstwa Warszawskiego. Trzeba jednak zwrócić uwagę na długotrwały okres głębokiej dyskryminacji i izolacji tej nacji na ziemiach polskich, poziom społecznych animozji - sprawa naprawienia tych błędów nie mogła być załatwiona od zaraz, tym bardziej w obliczu ogromnych problemów politycznych i finansowych świeżo odrodzonego, nie w pełni suwerennego skrawka państwowości polskiej. Różnego rodzaju restrykcje prawne skierowane wobec starozakonnych stosowano podówczas jeszcze szeroko w Europie, w tym nawet w postępowej Francji, większy zaś ich stopień na ziemiach Księstwa można tłumaczyć niższym poziomem rozwoju cywilizacyjnego, i to nie tylko samych Żydów, jak argumentuje w tej

99 Dekret z 6 XII 1811 r., Ustawodawstwo Ks. Warsz., t. III, s. 172-173 .

100 Generalne Urządzenie Żydów wprowadzało m.in. wspomniany obowiązek uzyskiwania zezwoleń na ślub żydowski (rozdz. V art. 9) i opłatę za ślub z Żydówką z zagranicy (rozdz. I art. 16), a także wyznaczało grupę zawodów, jakimi mogli parać się starozakonni (rozdz. III): handel (w miastach, kupcom wiejskim nakazano przeniesienie się do miast), rzemiosło (ze szczególnymi ograniczeniami na wsi), rolnictwo, hodowla bydła, furmaństwo, praca najemna. 
mierze Wacław Tokarz ${ }^{101}$, ale i ogółu społeczeństwa. Hasła rewolucji francuskiej okazały się bardziej teorią, na której zrealizowanie należało jeszcze poczekać. Proces ten na ziemiach polskich zyskał na tempie dopiero w drugiej połowie XIX wieku.

\section{Abstract \\ The restrictions of political and civil rights of Jewish population in the Duchy of Warsaw}

Established in 1807, the Duchy of Warsaw was subordinated to France. Napoleon preordered clearly to apply there the liberal, at that time, constitution and the decisive French civil code. Contrary to the hopes of Jewish population, that fact did not lead to equalization of their position with the rightful citizens. On 17 October 1808 a decree was issued cancelling all the political rights of Jews for the period of 10 years. Whereas on 19 November 1808 another decree definitely prohibited the Jews to purchase and to succeed to an estate (for the period of 10 years, as well).

Therefore, the Jews did not have the right to become members of parliament or to elect ones. The typical career of a Jewish citizen in such prestigious professions like lawyer was still quite impossible, they were forbidden to purchase the land in the country too. The old regulations establishing Jewish ghettos in cities were replaced by the regulations preventing the Jews from living along the posh streets. However, the authorities of the Duchy of Warsaw gave hopes for receiving the equality of rights for those Jews meritorious as far as the national interest was concerned or leaving their traditional way of life. Hence, the law regulations preventing them from living on certain streets gave exceptions to those of certain wealth, performed certain professions, were able to read and write in Polish, French or German, send their children to public schools or were dressed according to the modern European fashion.

Worth mentioning is the fact the total abandoning of Jewish faith and customs guaranteed the equal rights with Poles. Besides that the Jews were obliged to pay special tax duties, They were also limited in terms of

101 W. Tokarz, Z dziejów sprawy żydowskiej za Księstwa Warszawskiego, Kwartalnik Historyczny 1902, R. XVI, s. 266. 
economic freedom, especially as far as the prohibition of production and selling alcohol was concerned (the act from 30 October 1812). The clear aim of this law policy was to denationalize the Jewish minority and to restrict their economical power. It cannot be forgotten, however, that similar law and policy was introduced at that time in many other European countries, and the Duchy of Warsaw was by all means a temporary state of the country that did not have the chance for the real political, social and law development.

Keywords: Duchy of Warsaw, political rights, civil rights, Jews, restrictions 